\title{
A systematized review on diabetes gamification
}

\author{
Shadi Asadzandi ${ }^{1}$, Shahram Sedghi*1,2 (D) , Shoaleh Bigdeli ${ }^{3}$, Mahnaz Sanjari ${ }^{4,5}$ \\ Received: 10 Aug 2019 \\ Published: 14 Dec 2020
}

\begin{abstract}
Background: Gamification is an effective tool used to enhance the quality of education and training, to create motivation and enthusiasm, and to maintain competitiveness in the targeted population. Given that, the present study is an attempt to review gamification used in the field of diabetes systematically and its effects on the target group.

Methods: Articles were retrieved from eight databases via an electronic advanced search. The data were imported to Endnote; and to assess the quality of the articles, PRISMA and CASP were used. Finally, according to the inclusion criteria, the appropriate articles were selected.

Results: This study indicates that physical activity and nutrition were the most frequent diabetic subgroups in diabetes gamification. In addition, all diabetes gamification programs were designed to educate, teach skills and make behavior improvement in diabetics.

Conclusion: Diabetes gamification have the capacity to change health behaviors among all age groups and can create an innovative, attractive and interactive learning environment accompanied by fun and engagement. Professor, Health Management and Economics Research Center, Iran University of Medical Sciences, Tehran, Iran; Librarianship and Medical Information Science, Iran University of Medical Sciences, Tehran, Iran.
\end{abstract}

Keywords: Gamification, Video games, Serious game, Educational game, Diabetes

Conflicts of Interest: None declared

Funding: Iran University of Medical Sciences

*This work has been published under CC BY-NC-SA 1.0 license.

Copyright $@ \underline{\text { Iran University of Medical Sciences }}$

Cite this article as: Asadzandi S, Sedghi S, Bigdeli S, Sanjari M. A systematized review on diabetes gamification. Med J Islam Repub Iran. 2020 (14 Dec);34:168. https://doi.org/10.47176/mjiri.34.168

\section{Introduction}

Reports indicate that 422 million adults are diabetic, and its prevalence among adults over 18 years has risen to $8.5 \%$ in 2014 (1). According to the Center for Disease Control and Prevention (CDC) report, about $28.8 \%$ of the world population suffers from hidden diabetes (2). The prevalence of diabetes is estimated to be $6 \%$ in the Iranian population, and it is believed that about 4 million individuals are affected (3).

Diabetes is associated with serious complications and injuries, and several studies suggest that the rate of diabetic

\section{Corresponding author:Dr Shahram Sedghi, sedghi.s@iums.ac.ir}

1. Department of Librarianship and Medical Information Science School of Health Management and Information Sciences, Iran University of Medical Sciences, Tehran, Iran

2. Health Management and Economics Research Center, Iran University of Medical Sciences, Tehran, Iran

3. Center for Educational Research in Medical Sciences (CERMS), Department of Medical Education, School of Medicine, Iran University of Medical Sciences, Tehran, Iran

4. Diabetes Research Center, Endocrinology and Metabolism Clinical Sciences Institute, Tehran University of Medical Sciences, Tehran, Iran

5. Endocrinology and Metabolism Research Center, Endocrinology and Metabolism Clinical Sciences Institute, Tehran University of Medical Sciences, Tehran, Iran complications will increase in the near future, and it will occur at younger ages of life $(4,5)$. Therefore, it is necessary for diabetic patients to control their blood glucose levels to have a normal life and avoid unnecessary treatment costs. To achieve this goal, education of diabetics and healthy individuals to lower the risk of developing diabetes (6) and mainly increasing knowledge, awareness and attitude, acquiring necessary skills, enhancing coping with the disease, performing the required care, accelerating improvement and recovery, and minimizing the complications

$\uparrow$ What is "already known" in this topic:

Gamification increases motivation, creates fun and entertainment, and promotes learning.

\section{$\rightarrow$ What this article adds:}

Since health is a matter of life and death and treatment is a costly process, gamification can improve public health and decrease treatment costs through training healthy individuals to manage and enhance their health literacy. In addition, it is providing disease management training for high-risk groups and patients by creating fun and entertainment. 
is absolutely necessary (7-10). Today, educating people with emerging technological advances and multimedia encourages them to learn and develop an understanding of the disease, and adapt to the new information (11). Therefore, considering the high prevalence of diabetes in the world and its unwanted consequences, it is necessary to benefit from new educational technologies and instruments.

One of these technologies is gamification, which as an effective educational tool enhances the quality of education, creates motivation and enthusiasm, and develops a feeling of competition in the target population $(12,13)$. It has the potential to transform knowledge and educational content into personal knowledge to enable users to solve problems in an active or interactive manner (14). It should be mentioned that in addition to gamification, there are other tools such as a serious game (to combine aspects of both serious concept such as teaching, learning, communication, or further information with less entertainment (15), an educational game (for teaching the basic and certain subjects with enjoyment and pleasure (16)), game-based learning (to encourage learners to participate in learning while playing and make the learning process more interesting by adding fun (17)), that are used as tools to improve the learning process. These tools have their own specific features, but all of them have one purpose of increasing the level of learning along with increased motivation and entertainment. This study is an attempt to review and appraise all papers regarding the application of diabetes gamification, serious game, and/or educational games. In this study, diabetes gamification was examined to determine their purpose and features, their underpinning learning theories, and their impact on the target group. The main question is the effects of gamification on the target group. In this regard, the research attempts to provide a clear vision of diabetes gamifications.

\section{Methods}

On October 14-16, 2018, using an advanced search query, databases of PubMed, Ovid, Cochrane, Scopus, Web of Science, ProQuest, Springer, Embase, and Science Direct were searched to retrieve articles related to diabetes and games. The search operators included Booleans (AND, OR and NOT), parenthesis, and truncation. Example keywords and search query used to retrieve the papers were as follows:

(("diabetes mellitus, type1" OR "diabetes mellitus,

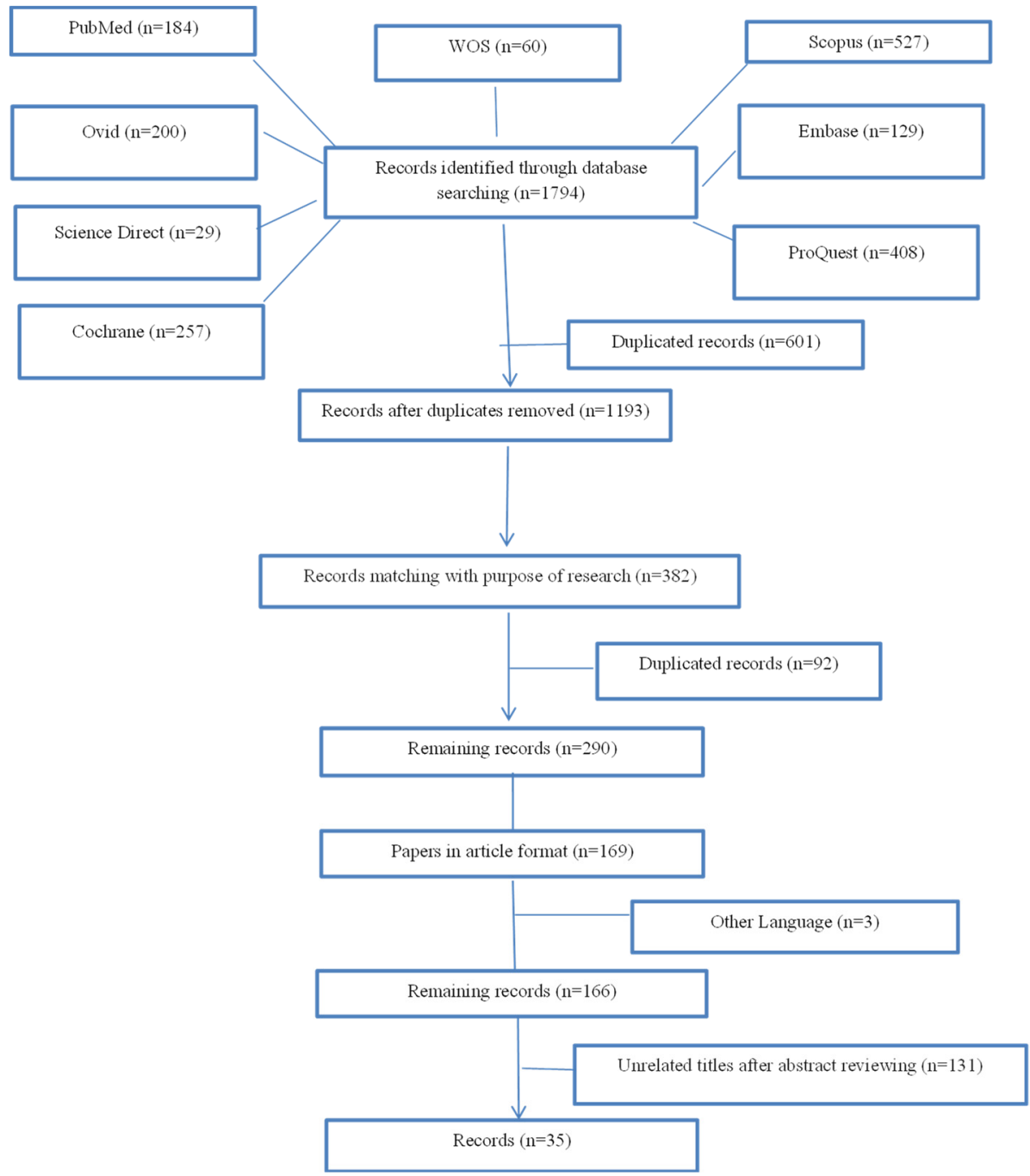

Flowchart 1. Assessment and selection of papers in the field of diabetes gamification 
type2") AND ("gamifications" OR "serious games" OR "educational games" OR "video games" OR "digital games" OR "Simulation" OR "Computer-assisted gaming" OR "Serious Game(s)" OR "Educational game(s)" OR "Role-playing game(s)" OR "Real-world game(s)" OR "massively multi player online" OR "role play simulation" OR "storytelling game"))

We applied the following inclusion criteria when filtering the search results: developing or using gamification/ serious game or educational game in the field of diabetes, availability of full texts of original research articles, language (English), with no limits regarding the publication time. The exclusion criteria include those which were not accessible due to sanctions. We excluded duplicates using Endnote V.7 and papers were reviewed and appraised by at least two members of the research team. Finally, inconsistencies were assessed and resolved, if there were any. The data extracted from each item were title, name(s) of author(s), publication place and year, research sample or population, type of study, objectives and research questions, and type of game. In addition, findings and results of each study were summarized and recorded in predesigned forms.
The PRISMA flowchart was used to investigate the retrieval, extraction and removal steps of articles as well as the Critical Appraisal Skills Program (CASP) for assessing the quality of the articles. The entire process of retrieving and reviewing studies is indicated in Flowchart 1.

\section{Results}

Bibliographic information of documents is presented in Table 1.

Table 1 shows that Leandro Arthur Diehl (LA Diehl) was a leading researcher in diabetes gamification with three publications related to the InsuOnline game. After him, Ch. Höchsmann, N. AOKI, and D. Thompson were in the second place with two articles. The oldest article about diabetes gamification was published in 1987. The highest rate of scientific productions in diabetes gamification was seen in 2016. Evaluation of journals showed that "Games for Health Journal: Research, Development, And Clinical Applications" published by Mary Ann Liebert Inc. has published the greatest number of articles in this field.

Classification of the retrieved data according to the names of the games and game producers and country of origin are presented in Table 2.

\begin{tabular}{|c|c|c|c|c|}
\hline Row & First Authors & Title & Journal & Year \\
\hline 1. & Klaassen, $\mathrm{R}$ & $\begin{array}{l}\text { Design and Evaluation of a Pervasive Coaching and } \\
\text { Gamification Platform for Young Diabetes Patients }\end{array}$ & Sensors & 2018 \\
\hline 2. & Diehl La & $\begin{array}{l}\text { InsuOnline, an Electronic Game for Medical Education } \\
\text { on Insulin Therapy: a Randomized Controlled Trial } \\
\text { With Primary Care Physicians }\end{array}$ & $\begin{array}{l}\text { Journal of Medical Inter- } \\
\text { net Research }\end{array}$ & 2017 \\
\hline 3. & Kerfoot, Bp & $\begin{array}{l}\text { a Team-Based Online Game Improves Blood Glucose } \\
\text { Control in Veterans with Type } 2 \text { Diabetes: a Random- } \\
\text { ized Controlled Trial }\end{array}$ & Diabetes Care & 2017 \\
\hline 4. & CalleBustos, A & $\begin{array}{l}\text { An Augmented Reality Game to Support Therapeutic } \\
\text { Education for Children with Diabetes }\end{array}$ & Plos One & 2017 \\
\hline 5. & $\begin{array}{l}\text { Blanson Henke- } \\
\text { mans, O }\end{array}$ & $\begin{array}{l}\text { Design And Evaluation of a Personal Robot Playing a } \\
\text { Self-Management Education Game with Children with } \\
\text { Diabetes Type } 1\end{array}$ & $\begin{array}{l}\text { International Journal of } \\
\text { Human-Computer Studies }\end{array}$ & 2017 \\
\hline 6. & $\begin{array}{l}\text { Eukel,H; Frenzel, } \\
\mathrm{J}\end{array}$ & $\begin{array}{l}\text { Educational Gaming for Pharmacy Students - Design } \\
\text { and Evaluation of a Diabetes-Themed Escape Room }\end{array}$ & $\begin{array}{l}\text { American Journal of Phar- } \\
\text { maceutical Education }\end{array}$ & 2017 \\
\hline 7. & Brinkmann, $\mathrm{Ch}$ & $\begin{array}{l}\text { Effects of Cycling and Exergaming On Neurotrophic } \\
\text { Factors in Elderly Type } 2 \text { Diabetic Men - a Preliminary } \\
\text { Investigation }\end{array}$ & $\begin{array}{l}\text { Experimental and Clinical } \\
\text { Endocrinology and Diabe- } \\
\text { tes }\end{array}$ & 2017 \\
\hline 8. & Höchsmann, Ch & $\begin{array}{l}\text { Mobile Exergaming for Health-Effects of a Serious } \\
\text { Game Application For Smartphones on Physical Activ- } \\
\text { ity and Exercise Adherence in Type } 2 \text { Diabetes Melli- } \\
\text { tus-Study Protocol for a Randomized Controlled Trial }\end{array}$ & Trials & 2017 \\
\hline 9. & Ledoux, $\mathrm{T}$ & $\begin{array}{l}\text { an Educational Video Game for Nutrition Of Young } \\
\text { People: Theory and Design }\end{array}$ & Simul Gaming & 2016 \\
\hline 10. & Maas $\mathrm{AH}$ & $\begin{array}{l}\text { Concept Development of The Eindhoven Diabetes Ed- } \\
\text { ucation Simulator Project }\end{array}$ & $\begin{array}{l}\text { Games for Health Journal: } \\
\text { Research, Development, } \\
\text { and Clinical Application }\end{array}$ & 2016 \\
\hline 11. & Baghaei, $\mathrm{N}$ & $\begin{array}{l}\text { Diabetic Mario: Designing and Evaluating Mobile } \\
\text { Games for Diabetes Education }\end{array}$ & $\begin{array}{l}\text { Games for Health Journal: } \\
\text { Research, Development, } \\
\text { and Clinical Applications }\end{array}$ & 2016 \\
\hline 12. & Joubert, M & $\begin{array}{l}\text { Impact of a Serious Videogame Designed for Flexible } \\
\text { Insulin Therapy on The Knowledge and Behaviors of } \\
\text { Children with Type } 1 \text { Diabetes: The Ludidiab Pilot } \\
\text { Study }\end{array}$ & $\begin{array}{l}\text { Diabetes Technology \& } \\
\text { Therapeutics }\end{array}$ & 2016 \\
\hline 13. & Jingjing, W & $\begin{array}{l}\text { Acceptability and Applicability of an American Health } \\
\text { Videogame with Story for Childhood Obesity Preven- } \\
\text { tion Among Hong Kong Chinese Children Research }\end{array}$ & $\begin{array}{l}\text { Games for Health Journal: } \\
\text { Research, Development, } \\
\text { and Clinical Applications }\end{array}$ & 2015 \\
\hline
\end{tabular}




\begin{tabular}{|c|c|c|c|c|}
\hline Row & Authors & Title & Journal & Year \\
\hline 1. & Ebrahimpour, F & $\begin{array}{l}\text { Effect of Playing Interactive Computer Game on Distress of } \\
\text { Insulin Injection Among Type } 1 \text { Diabetic Children }\end{array}$ & $\begin{array}{l}\text { Iranian Journal of Pedi- } \\
\text { atrics }\end{array}$ & 2015 \\
\hline 2. & Diehl, L & $\begin{array}{l}\text { Effectiveness of a Serious Game } \\
\text { for Medical Education on Insulin Therapy: a Pilot Study }\end{array}$ & Arch Endocrinol Metab & 2015 \\
\hline 3. & Höchsmann, Ch & $\begin{array}{l}\text { Cardiorespiratory Exertion While Playing Video Game Ex- } \\
\text { ercises in Elderly Individuals with Type } 2 \text { Diabetes }\end{array}$ & $\begin{array}{l}\text { Clinical Journal of Sport } \\
\text { Medicine }\end{array}$ & 2015 \\
\hline 4. & Diehl, L & $\begin{array}{l}\text { User Assessment of "'Insuonline," a Game to Fight Clinical } \\
\text { Inertia in Diabetes: a Pilot Study }\end{array}$ & $\begin{array}{l}\text { Games for Health Jour- } \\
\text { nal: Research, Develop- } \\
\text { ment, and Clinical Ap- } \\
\text { plications }\end{array}$ & 2015 \\
\hline 5. & Ebrahimpour, F & $\begin{array}{l}\text { The Design And Development of a Computer Game on In- } \\
\text { sulin Injection }\end{array}$ & Electronic Physician & 2014 \\
\hline 6. & Patterson, D & $\begin{array}{l}\text { Using Interactive } 3 \mathrm{~d} \text { Game Play to Make Complex Medical } \\
\text { Knowledge More Accessible }\end{array}$ & $\begin{array}{l}\text { Procedia Computer Sci- } \\
\text { ence }\end{array}$ & 2014 \\
\hline 7. & Kempf, K & $\begin{array}{l}\text { Autonomous Exercise Game Use Improves Metabolic Con- } \\
\text { trol and Quality of Life in Type } 2 \text { Diabetes Patients - a Ran- } \\
\text { domized Controlled Trial }\end{array}$ & $\begin{array}{l}\text { BMC Endocrine Disor- } \\
\text { ders }\end{array}$ & 2013 \\
\hline 8. & $\begin{array}{l}\text { Anderson-Hanley, } \\
\text { C }\end{array}$ & $\begin{array}{l}\text { Neuropsychological Benefits of Stationary Bike Exercise } \\
\text { and a Cybercycle Exergame for Older Adults with Diabe- } \\
\text { tes: an Exploratory Analysis }\end{array}$ & $\begin{array}{l}\text { Journal of Diabetes Sci- } \\
\text { ence and Technology }\end{array}$ & 2012 \\
\hline 9. & Noah, J & Vigorous Energy Expenditure with a Dance Exergame & $\begin{array}{l}\text { Journal of Exercise } \\
\text { Physiology Online }\end{array}$ & 2011 \\
\hline 10. & Johnston, H & $\begin{array}{l}\text { Pose Presentation for } \mathrm{f} \text { Dance-Based Massively Multiplayer } \\
\text { Online Exergame }\end{array}$ & $\begin{array}{l}\text { Entertainment Compu- } \\
\text { ting }\end{array}$ & 2011 \\
\hline 11. & Fuchslocher, A & $\begin{array}{l}\text { Serious Games for Health: an Empirical Study of The Game } \\
\text { "Balance", for Teenagers with Diabetes Mellitus }\end{array}$ & $\begin{array}{l}\text { Entertainment Compu- } \\
\text { ting }\end{array}$ & 2011 \\
\hline 12. & Klingensmitha, G & $\begin{array}{l}\text { Evaluation of a Combined Blood Glucose Monitoring and } \\
\left.\text { Gaming System (Didget }{ }^{\circledR}\right) \text { for Motivation in Children, Ad- } \\
\text { olescents, and Young Adults with Type } 1 \text { Diabetes }\end{array}$ & Pediatric Diabetes & 2011 \\
\hline 13. & Thompson, D & $\begin{array}{l}\text { Serious Video Games for Health How Behavioral Science } \\
\text { Guided }\end{array}$ & Simul Gaming & 2010 \\
\hline 14. & Deshazo, J & $\begin{array}{l}\text { The Development of a Serious Video Game } \\
\text { Designing and Remotely Testing Mobile Diabetes Video } \\
\text { Games }\end{array}$ & $\begin{array}{l}\text { Journal of Telemedicine } \\
\text { and Telecare }\end{array}$ & 2010 \\
\hline 15. & Thompson, D & $\begin{array}{l}\text { In Pursuit of Change: Youth Response to Intensive Goal } \\
\text { Setting Embedded in a Serious Video Game }\end{array}$ & $\begin{array}{l}\text { Journal of Diabetes Sci- } \\
\text { ence and Technology }\end{array}$ & 2007 \\
\hline 16. & Aoki, N & $\begin{array}{l}\text { Insulot: a Cellular Phone-Based Edutainment Learning Tool } \\
\text { for Children with Type } 1 \text { Diabetes }\end{array}$ & Diabetes Care & 2005 \\
\hline 17. & Aoki, N & $\begin{array}{l}\text { Edutainment Tools for Initial Education of Type-1 Diabetes } \\
\text { Mellitus: Initial Diabetes Education With Fun }\end{array}$ & $\begin{array}{l}\text { Studies in Health Tech- } \\
\text { nology and Informatics }\end{array}$ & 2004 \\
\hline 18. & Sherwood, N & $\begin{array}{l}\text { Development And Implementation of a Visual Card sorting } \\
\text { Technique for Assessing Food and Activity Preferences and } \\
\text { Patterns in African American Girls }\end{array}$ & $\begin{array}{l}\text { Journal of The Ameri- } \\
\text { can Dietetic Association }\end{array}$ & 2003 \\
\hline 19. & Brown, S. J & $\begin{array}{l}\text { Educational Video Game for Juvenile Diabetes: Results of a } \\
\text { Controlled Trial }\end{array}$ & $\begin{array}{l}\text { JMIR Medical Informat- } \\
\text { ics }\end{array}$ & 1997 \\
\hline 20. & Boswell, E & $\begin{array}{l}\text { The Activity: a Tool for Teaching How to Adjust for Exer- } \\
\text { cise Variations }\end{array}$ & The Diabetes Educator & 1997 \\
\hline 21. & Davidson, $\mathrm{N}$ & Games: Teaching Strategy for Professionals & The Diabetes Educator & 1989 \\
\hline 22. & Wheeler, L & $\begin{array}{l}\text { Betakid\&Mdash;Lessons Learned While Developing a Mi- } \\
\text { crocomputer Pediatric Case Simulation }\end{array}$ & The Diabetes Educator & 1987 \\
\hline
\end{tabular}

Game production costs were not mentioned in these articles, but the costs of playing the games in the majority of these researches were free. In addition, it was indicated that to produce an appropriate gamification, we need a team consisting of technical experts and health professionals.

Figure 1 presents the distribution of gamification producers according to the country of production.

It indicates that most gamifications are produced in the USA, and the rest of the countries with the least productions
(1 or 2 games) stand in lower positions.

Characteristics of gamification, including game objectives, specifications, underpinning learning theories and characteristics of participants, are presented in Table 3.

This is evident from the data as presented in Table 3 that all games were designed to educate, teach skills and make behavior improvement for diabetics and they are less attended to train healthcare providers or healthy people. Ac- 
Table 2. The names of the games and the countries of origin in the field of diabetes

\begin{tabular}{|c|c|c|c|c|}
\hline Row & Title & Game name & Developing Team & $\begin{array}{l}\text { Country pro- } \\
\text { duction }\end{array}$ \\
\hline 1. & $\begin{array}{l}\text { Design And Evaluation of a Pervasive Coaching and Gamifi- } \\
\text { cation Platform for Young Diabetes Patients }\end{array}$ & Virtual coach & Not Mentioned & England \\
\hline 2. & $\begin{array}{l}\text { Insuonline, an Electronic Game for Medical Education on In- } \\
\text { sulin Therapy: a Randomized Controlled Trial with Primary } \\
\text { Care Physicians }\end{array}$ & InsuOnline & $\begin{array}{l}\text { Clinical endocrinologists, } \\
\text { game designers, experts in } \\
\text { medical education, and } \\
\text { programmers, graphic de- } \\
\text { signers, sound editors }\end{array}$ & $\begin{array}{l}\text { Not Men- } \\
\text { tioned }\end{array}$ \\
\hline 3. & $\begin{array}{l}\text { A Team-Based Online Game Improves Blood Glucose Con- } \\
\text { trol in Veterans with Type } 2 \text { Diabetes: a Randomized Con- } \\
\text { trolled Trial }\end{array}$ & DSME game & Not Mentioned & USA \\
\hline 4. & $\begin{array}{l}\text { An Augmented Reality Game to Support Therapeutic Educa- } \\
\text { tion for Children With Diabetes }\end{array}$ & TED & Experts in diet & Venezuela \\
\hline 5. & $\begin{array}{l}\text { Design and Evaluation of a Personal Robot Playing a Self- } \\
\text { Management Education Game with Children with Diabetes } \\
\text { Type } 1\end{array}$ & A robot & Not Mentioned & Netherlands \\
\hline 6. & $\begin{array}{l}\text { Educational Gaming for Pharmacy Students - Design and } \\
\text { Evaluation of A Diabetes-Themed Escape Room }\end{array}$ & $\begin{array}{l}\text { The diabetes es- } \\
\text { cape room }\end{array}$ & $\begin{array}{l}\text { Pharmacy Faculty mem- } \\
\text { bers }\end{array}$ & USA \\
\hline 7. & $\begin{array}{l}\text { Effects of Cycling and Exergaming on neurotropic Factors in } \\
\text { Elderly Type } 2 \text { Diabetic Men - a Preliminary Investigation }\end{array}$ & Wii Fit Plus & Not mentioned & Germany \\
\hline 8. & $\begin{array}{l}\text { Mobile Exergaming for Health Effects of a serious game ap- } \\
\text { plication for smartphones on physical activity and exercise } \\
\text { adherence in type } 2 \text { diabetes mellitus-study protocol for a } \\
\text { randomized controlled trial }\end{array}$ & Mobigame & Not mentioned & Switzerland \\
\hline 9. & $\begin{array}{l}\text { An Educational Video Game for Nutrition of Young People: } \\
\text { Theory and Design }\end{array}$ & $\begin{array}{l}\text {-Escape from } \\
\text { DIAB } \\
\text {-Nanoswarm }\end{array}$ & $\begin{array}{l}\text { Nutrition and physical ac- } \\
\text { tivity experts, with a game } \\
\text { development company } \\
\text { (Archimage Inc.) }\end{array}$ & USA \\
\hline 10. & $\begin{array}{l}\text { Concept Development of The Eindhoven Diabetes Education } \\
\text { Simulator Project }\end{array}$ & $\begin{array}{l}\text { Eindhoven Diabe- } \\
\text { tes Education Sim- } \\
\text { ulator (E-DES) }\end{array}$ & Not Mentioned & Denmark \\
\hline 11. & $\begin{array}{l}\text { Diabetic Mario: Designing and Evaluating Mobile Games for } \\
\text { Diabetes Education }\end{array}$ & Mario Brothers & Not mentioned & New Zealand \\
\hline 12. & $\begin{array}{l}\text { Impact of a Serious Videogame Designed for Flexible Insu- } \\
\text { lin Therapy on the Knowledge and Behaviors of Children } \\
\text { with Type } 1 \text { Diabetes: The LUDIDIAB Pilot Study }\end{array}$ & L'Affaire Birman & $\begin{array}{l}\text { An academic diabetes care } \\
\text { team, including physi- } \\
\text { cians, dieticians, nurses, } \\
\text { and expert patients with } \\
\text { diabetes. Game play, } \\
\text { graphic design, sound- } \\
\text { scape, and story. }\end{array}$ & France \\
\hline 13. & $\begin{array}{l}\text { Acceptability and Applicability of An American Health Vid- } \\
\text { eogame with Story for Childhood Obesity Prevention } \\
\text { Among Hong Kong Chinese Children Research }\end{array}$ & Diab & Not mentioned & USA \\
\hline 14. & $\begin{array}{l}\text { Effect of Playing Interactive Computer Game on Distress of } \\
\text { Insulin Injection Among Type } 1 \text { Diabetic Children }\end{array}$ & Koodak-e-Tavana & Not mentioned & Iran \\
\hline 15. & $\begin{array}{l}\text { Effectiveness of A Serious Game for Medical Education on } \\
\text { Insulin Therapy: a Pilot Study }\end{array}$ & InsuOnline & $\begin{array}{l}\text { Clinical endocrinologists, } \\
\text { game designers, experts in } \\
\text { medical education, and } \\
\text { programmers, graphic de- } \\
\text { signers }\end{array}$ & Brazil \\
\hline 16. & $\begin{array}{l}\text { Cardiorespiratory Exertion While Playing Video Game Exer- } \\
\text { cises in Elderly Individuals with Type } 2 \text { Diabetes }\end{array}$ & $\begin{array}{l}\text { Nintendo Wii Fit } \\
\text { Plus }\end{array}$ & Not mentioned & USA \\
\hline 17. & $\begin{array}{l}\text { User Assessment of Insuonline, a Game to Fight Clinical In- } \\
\text { ertia In Diabetes: a Pilot Study }\end{array}$ & InsuOnline & $\begin{array}{l}\text { Clinical endocrinologists, } \\
\text { game designers, experts in } \\
\text { medical education, and } \\
\text { programmers, graphic de- } \\
\text { signers }\end{array}$ & Brazil \\
\hline 18. & $\begin{array}{l}\text { The Design and Development of a Computer Game on Insu- } \\
\text { lin Injection }\end{array}$ & Koodak-e-Tavana & Not mentioned & Iran \\
\hline 19. & $\begin{array}{l}\text { Using Interactive 3d Game Play to Make Complex Medical } \\
\text { Knowledge More Accessible }\end{array}$ & $\begin{array}{l}\text { Diabetes Visual- } \\
\text { izer }\end{array}$ & Not mentioned & Australia \\
\hline
\end{tabular}

cording to the title or game features, some games are considered as educational game such as the diabetes escape room, Escape from DIAB, Nanoswarm and Packy \& Marlon or some of them are serious games such as Mobigame, L'Affaire Birman, InsuOnline and Balance which means that all types of games were retrieved based on the purpose of the research. Most of these games are mobile-based; however, some of them were designed for game consoles or game boards. Assessment of learning theories used in these gamifications showed that self-determination theory was frequently applied in games such as Virtual coach, robot, Escape from DIAB and Diab. Classification of games according to Bloom's Taxonomy of Behavioral Objectives showed that 


\begin{tabular}{|c|c|c|c|c|}
\hline Row & Title & Game name & Developing Team & $\begin{array}{l}\text { Country pro- } \\
\text { duction }\end{array}$ \\
\hline 20. & $\begin{array}{l}\text { Autonomous Exercise Game Use Improves Meta- } \\
\text { bolic Control and Quality Of Life in Type } 2 \text { Diabetes } \\
\text { Patients - a Randomized Controlled Trial }\end{array}$ & Wii Fit Plus & Not mentioned & Germany \\
\hline 21. & $\begin{array}{l}\text { Neuropsychological Benefits of Stationary Bike Ex- } \\
\text { ercise and a Cybercycle Exergame for Older Adults } \\
\text { with Diabetes: an Exploratory Analysis }\end{array}$ & Cybercycle & Not mentioned & USA \\
\hline 22. & $\begin{array}{l}\text { Vigorous Energy Expenditure with a Dance Exer- } \\
\text { game }\end{array}$ & Dance Dance Revolution & Not mentioned & USA \\
\hline 23. & $\begin{array}{l}\text { Pose Presentation for a Dance-Based Massively Mul- } \\
\text { tiplayer Online Exergame }\end{array}$ & SNAP system & Not mentioned & Canada \\
\hline 24. & $\begin{array}{l}\text { Serious Games For Health: An Empirical Study Of } \\
\text { The Game "Balance"' for Teenagers With Diabetes } \\
\text { Mellitus }\end{array}$ & Balance & $\begin{array}{l}\text { Medical scientists and } \\
\text { psychologists of the LMU } \\
\text { Munich child hospital }\end{array}$ & Germany \\
\hline 25. & $\begin{array}{l}\text { Evaluation of A Combined Blood Glucose Monitor- } \\
\text { ing and Gaming System (Didget } ® \text { ) for Motivation in } \\
\text { Children, Adolescents, and Young Adults with Type } \\
1 \text { Diabetes }\end{array}$ & Didget & Not mentioned & USA \\
\hline 26. & $\begin{array}{l}\text { Serious Video Games for Health How Behavioral } \\
\text { Science Guided The Development of a Serious } \\
\text { Video Game }\end{array}$ & Escape From Diab & $\begin{array}{l}\text { Producer, director, video } \\
\text { artists, animators, pro- } \\
\text { grammers, modelers, story } \\
\text { writers, music composers, } \\
\text { sound editors, storyboard } \\
\text { artists, and voice talent. }\end{array}$ & USA \\
\hline 27. & $\begin{array}{l}\text { Designing and remotely testing mobile diabetes } \\
\text { video games }\end{array}$ & $\begin{array}{l}\text {-Hangman } \\
\text {-QuizShow } \\
\text {-Countdown }\end{array}$ & Not mentioned & USA \\
\hline 28. & $\begin{array}{l}\text { In Pursuit of Change: Youth Response to Intensive } \\
\text { Goal Setting Embedded in a Serious Video Game }\end{array}$ & Nanoswarm & Not mentioned & USA \\
\hline 29. & $\begin{array}{l}\text { INSULOT: a cellular phone-based edutainment } \\
\text { learning tool for children with type } 1 \text { diabetes }\end{array}$ & INSULOT & $\begin{array}{l}\text { This research was sup- } \\
\text { ported in part by grants } \\
\text { from the Pfizer Health Re- } \\
\text { search Foundation (To- } \\
\text { kyo, Japan) and TOSE } \\
\text { (Kyoto, Japan) for their } \\
\text { support in the develop- } \\
\text { ment of the application }\end{array}$ & Japan \\
\hline 30. & $\begin{array}{l}\text { Edutainment tool for initial education type } 1 \text { diabetes } \\
\text { mellitus: initial diabetes with fun }\end{array}$ & $\begin{array}{l}\text {-Tamagoya } \\
\text {-Tantei } \\
\text {-Magic Toom }\end{array}$ & $\begin{array}{l}\text { Diabetes specialties and } \\
\text { nurses }\end{array}$ & Japan \\
\hline 31. & $\begin{array}{l}\text { Development and implementation of a visual card } \\
\text { sorting technique for assessing food and activity } \\
\text { preferences and patterns in African American girls }\end{array}$ & Not mentioned & Not mentioned & USA \\
\hline 32. & $\begin{array}{l}\text { Educational video game for juvenile diabetes: results } \\
\text { of a controlled trial }\end{array}$ & Packy \& Marlon & Not mentioned & USA \\
\hline 33. & $\begin{array}{l}\text { The Activity Activity: a Tool for Teaching How to } \\
\text { Adjust for Exercise Variations }\end{array}$ & Activity Activity & Not mentioned & USA \\
\hline 34. & Games: Teaching Strategy for Professionals & $\begin{array}{l}\text {-Tic-Tac-Diabetes } \\
\text {-What's wrong with This } \\
\text { Picture? } \\
\text {-Can You Guess Your } \\
\text { Blood Sugar'? }\end{array}$ & Not mentioned & Not mentioned \\
\hline 35. & $\begin{array}{l}\text { Betakid\&mdash; Lessons Learned While Developing } \\
\text { a Microcomputer Pediatric Case Simulation }\end{array}$ & Betakid & $\begin{array}{l}\text { a pediatric diabetologist, } \\
\text { pediatric nurse clinicians, } \\
\text { an instructional designer, } \\
\text { and a physician }\end{array}$ & USA \\
\hline
\end{tabular}

most gamifications could be classified under a cognitive domain (application and knowledge levels); in this regard, exergames consider the psychomotor activity and could be classified under this domain. Considering the effectiveness of games, the retrieved data indicated that gamification in each platform and genre could meet the participants' needs and encourage their participation.

According to Table 3 , the target population of the gamifications was from different age groups including children, diabetic patients, and healthy people and the games were designed for medical students and residents, or students of other related medical majors. There was a marked variation in the type of diabetes and many gamifications encompassed both types. Physical activity and nutrition (14 papers) were the most frequent diabetic subthemes in diabetes gamifications.

\section{Discussion}

Gamification is one of the learning methods that has been much considered in recent years $(18,19)$. According to Gee, the purpose of gamification is to create a problemsolving environment that can be integrated with continuous 


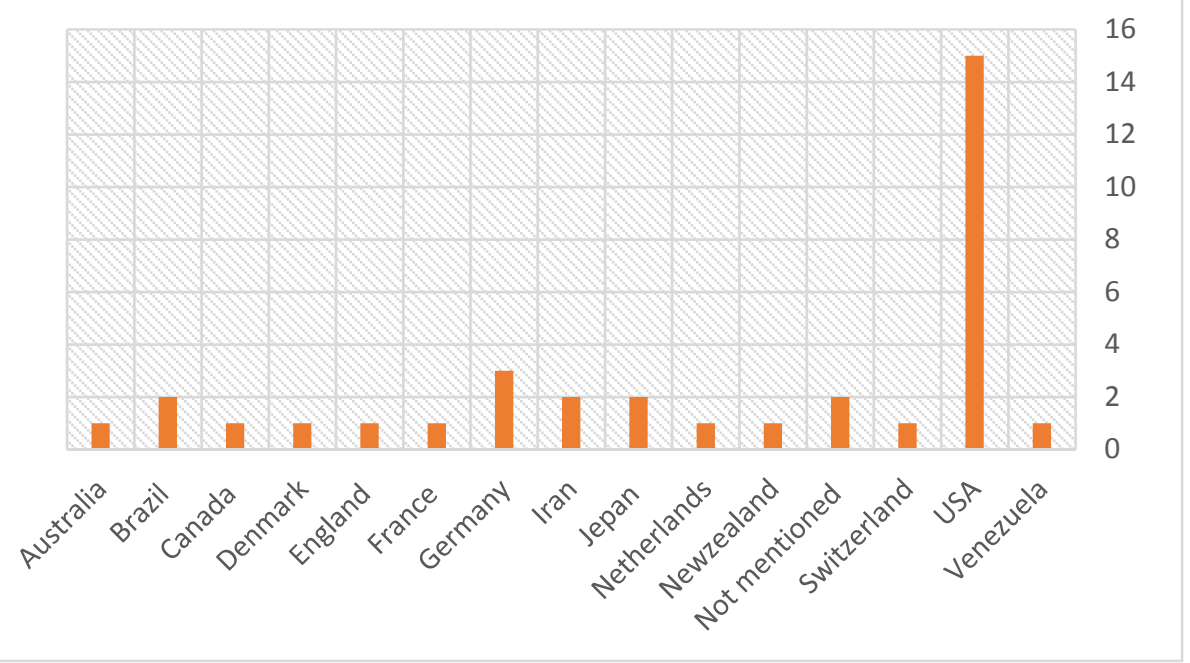

Fig. 1. Distribution of diabetes gamification in terms of country of origin

education and enjoyment for improving the learning process (20). Therefore, in this review, the features, educational aspects and effectiveness of gamification (serious, educational games) in diabetes (both types) were investigated.

In this systematized review, 1795 papers were retrieved from eight databases. After discarding unrelated papers that did not match the purposes of this study, 35 papers met the study criteria.

Assessment of characteristics and commonalities among diabetes gamification showed that they were designed as digital games, exergames requiring sensors and motion detectors, and board games. They are all problem-solving games that use the task and goal method in gamification, to deliver teaching indirectly, to help learners learn through missions, tasks, victories, and failures $(21,22)$. Considering the game design, all the related games, except the games for teaching physical skills (exergames), use multiplechoice questions to convey game concepts (23-25).

In addition, considering underpinning learning theories to develop gamification is crucial (26). These theories promote learning and improve skills such as problem-solving and critical thinking (27-29). In this research, all diabetes gamifications aimed at teaching a skill or concept, changing a behavior or habit positively, or enhancing disease management in the target population and most of them benefited from one or more implicit underpinning learning theories.

More, gamification targets knowledge and skills and transfers them to the learner through elements such as repetition, feedback, and entertainment. When the learner becomes skillful, knowledge and skills related to that concept become persistent in the memory so that the learner can focus on the perception and implementation of the information. On the other hand, gamification has positive effects on motivation and decision-making capabilities, because the player faces challenges that untimely enhance learning through decision-making, discovery, and trial and error (18, $30,31)$. This scientific background is the backbone of the effectiveness of gamification (32-34). It is also consistent with the results of this study since the target populations of diabetes gamification could successfully receive and implement the required knowledge and skills. However, it should be noted that retention of information learned through gamification was not assessed in these studies.

Considering diabetes gamification developing team, it is revealed that in addition to the field professionals, an expert technical team, including game design experts, programmers, concept designers, art designers, graphic designer, character designer, and sound designers must be among the game production team members, because identification of the technical, artistic and aesthetic aspects of the game are of paramount importance besides mastery over the gamification topic and field, which is also associated with high financial costs. On the other hand, the use of several advanced technologies, software, and hardware increases the costs of gamification production and is highly challenging (35-37).

Research limitations include the inaccessibility of some databases that do not permit the researchers to access full texts of all related articles.

\section{Conclusion}

The research findings indicate that all studies confirm the effectiveness of gamification in the users' training, and of course, encourage other researchers in other clinical fields to develop gamification or serious games, especially in the disciplines where understanding and learning are tedious and challenging. Since health is a matter of life and death and treatment is a costly process, gamification can improve public health and decrease treatment costs through training healthy individuals to manage and enhance their health literacy or providing disease management training for highrisk groups and patients by creating fun and entertainment. Finally, it is suggested that in future studies on gamification, the application of learning theories in gamification and serious games be the focus of attention. 


\begin{tabular}{|c|c|c|c|c|c|c|c|c|c|}
\hline Row & Game name & $\mathrm{Aim} / \mathrm{s}$ & Features & $\begin{array}{l}\text { Learning Domain } \\
\text { (subdomain) }\end{array}$ & Learning Theory & Effectiveness & $\begin{array}{l}\text { Target Audience/ } \\
\text { gender }\end{array}$ & $\begin{array}{c}\text { Type of Di- } \\
\text { abetes }\end{array}$ & Target Aspects \\
\hline 1. & Virtual coach & $\begin{array}{l}\text { To Develop integrated } \\
\text { pervasive coaching } \\
\text { and gamification plat- } \\
\text { forms in medical prac- } \\
\text { tice }\end{array}$ & $\begin{array}{l}\text { Created with the PERGAMON framework } \\
\text { consisting of: a web application, an Android } \\
\text { application for gathering data from sensors. } \\
\text { PERGAMON platform is Tasks and Goals and } \\
\text { assigns a certain number of points. }\end{array}$ & $\begin{array}{c}\text { Cognitive } \\
\text { (Knowledge) }\end{array}$ & $\begin{array}{l}\text { Self-Determina- } \\
\text { tion }\end{array}$ & $\begin{array}{l}\text { mobile technology }+ \\
\text { web-based elements } \\
\text { supports self-man- } \\
\text { agement } \\
\text { in diabetics }\end{array}$ & $\begin{array}{c}\text { Not men- } \\
\text { tioned/Both }\end{array}$ & Type 1 & $\begin{array}{c}\text { Self-management } \\
\text { and Treatment }\end{array}$ \\
\hline 2. & InsuOnline & $\begin{array}{l}\text { To assess the effec- } \\
\text { tiveness of InsuOnline } \\
\text { as a method for on in- } \\
\text { sulin therapy for dia- } \\
\text { betes, as compared } \\
\text { with a traditional on- } \\
\text { site educational activ- } \\
\text { ity }\end{array}$ & $\begin{array}{l}\text { A Blender 3D app, with simple commands. } \\
\text { Unity-based with visual elements }\end{array}$ & $\begin{array}{l}\text { Cognitive (Appli- } \\
\text { cation) }\end{array}$ & $\begin{array}{l}\text { Problem-based } \\
\text { learning }\end{array}$ & $\begin{array}{l}\text { effective for medical } \\
\text { education on insulin } \\
\text { therapy highly }\end{array}$ & $\begin{array}{l}\text { Primary care phy- } \\
\text { sicians with any } \\
\text { Degree of Com- } \\
\text { puter or Gaming } \\
\text { Literacy/Both }\end{array}$ & $\begin{array}{l}\text { Diabetes } \\
\text { Mellitus }\end{array}$ & Insulin Therapy \\
\hline 3. & DSME game & $\begin{array}{l}\text { To generate longer- } \\
\text { term improvements in } \\
\text { hemoglobin } \mathrm{A}_{1 \mathrm{c}} \\
\left(\mathrm{HbA}_{1 \mathrm{c}}\right) \text { by online } \\
\text { team-based game de- } \\
\text { livering diabetes self- } \\
\text { management education } \\
\text { for patients via e-mail } \\
\text { or mobile application }\end{array}$ & $\begin{array}{l}\text { An automated system with multiple-choice } \\
\text { questions }\end{array}$ & $\begin{array}{l}\text { Cognitive (Appli- } \\
\text { cation) }\end{array}$ & Not Mentioned & $\begin{array}{l}\text { To improve out- } \\
\text { comes among geo- } \\
\text { graphically dis- } \\
\text { persed patients with } \\
\text { diabetes }\end{array}$ & $\begin{array}{l}\text { Patients on Oral } \\
\text { Diabetes Medica- } \\
\text { tions /Male }\end{array}$ & Type 2 & $\begin{array}{c}\text { Self-management } \\
\text { and Treatment }\end{array}$ \\
\hline 4. & TED & $\begin{array}{l}\text { To take responsibility } \\
\text { for self-control in dia- } \\
\text { betic patients }\end{array}$ & $\begin{array}{l}\text { The game runs on a mobile } \\
\text { device with an Android Operating System and } \\
\text { has } 3 \text { levels, each of which focuses on a food } \\
\text { group. the } \\
\text { three food groups are: dairy products, farina- } \\
\text { ceous products (grains), and fruits }\end{array}$ & $\begin{array}{l}\text { Cognitive (Appli- } \\
\text { cation) }\end{array}$ & $\begin{array}{l}\text { self-Determina- } \\
\text { tion }\end{array}$ & $\begin{array}{l}\text { Children acquired } \\
\text { new knowledge } \\
\text { about carb } \\
\text { choices in the short- } \\
\text { term and facilitate in } \\
\text { the } \\
\text { learning process. }\end{array}$ & $\begin{array}{l}\text { Children, } 5-14 \\
\text { years old /Both }\end{array}$ & Both & Nutrition \\
\hline 5. & A robot & $\begin{array}{l}\text { To assess a personal } \\
\text { robot in diabetes self- } \\
\text { management/ } \\
\text { To Acquire knowledge } \\
\text { about the illness }\end{array}$ & $\begin{array}{l}\text { Autonomous, programmable humanoid robot } \\
\text { with quiz, and training skills(social, individual, } \\
\text { decision-making) }\end{array}$ & $\begin{array}{l}\text { Cognitive (Appli- } \\
\text { cation) }\end{array}$ & $\begin{array}{l}\text { Self-Determina- } \\
\text { tion }\end{array}$ & $\begin{array}{l}\text { To improve self- } \\
\text { management and } \\
\text { cope with illness in } \\
\text { diabetic children }\end{array}$ & $\begin{array}{l}\text { Children, } 5-14 \\
\text { years old /Both }\end{array}$ & Both & Nutrition \\
\hline
\end{tabular}




\begin{tabular}{|c|c|c|c|c|c|c|c|c|c|}
\hline Row & Game name & $\mathrm{Aim} / \mathrm{s}$ & Features & $\begin{array}{c}\text { Learning Do- } \\
\text { main(subdomain) }\end{array}$ & Learning Theory & Effectiveness & $\begin{array}{l}\text { Target Audi- } \\
\text { ence/ gender }\end{array}$ & $\begin{array}{c}\text { Type of } \\
\text { Diabetes }\end{array}$ & Target Aspects \\
\hline 6. & $\begin{array}{l}\text { The diabetes es- } \\
\text { cape room }\end{array}$ & $\begin{array}{l}\text { To enhance } \\
\text { pharmacy and inter- } \\
\text { professional education } \\
\text { To increase knowledge } \\
\text { of } \\
\text { diabetes management }\end{array}$ & $\begin{array}{l}\text { Live-action } \\
\text { team-based games with a specific goal, as well } \\
\text { as discovering clue and } \\
\text { solving puzzles }\end{array}$ & $\begin{array}{l}\text { Cognitive (Appli- } \\
\text { cation) }\end{array}$ & Cognitive & $\begin{array}{l}\text { increased students' } \\
\text { knowledge of diabe- } \\
\text { tes mellitus manage- } \\
\text { ment }\end{array}$ & $\begin{array}{l}\text { 7-12 Children, } \\
\text { years old /Both }\end{array}$ & Type 1 & $\begin{array}{c}\text { Self-manage- } \\
\text { ment }\end{array}$ \\
\hline 7. & Wii Fit Plus & $\begin{array}{l}\text { To evaluate the suita- } \\
\text { bility of the Wii Fit } \\
\text { Plus to improve cardi- } \\
\text { orespiratory fitness in } \\
\text { type } 2 \text { diabetes }\end{array}$ & $\begin{array}{l}\text { Nintendo's exergame, Combination of physical } \\
\text { activity and video games }\end{array}$ & $\begin{array}{l}\text { Cognitive (Evalu- } \\
\text { ation) }\end{array}$ & Not Mentioned & $\begin{array}{l}\text { Improve cardi- } \\
\text { orespiratory fitness } \\
\text { and glucose metabo- } \\
\text { lism }\end{array}$ & $\begin{array}{l}\text { Third-year Pro- } \\
\text { fessional Phar- } \\
\text { macy Students } \\
\text { /Both }\end{array}$ & $\begin{array}{l}\text { Diabetes } \\
\text { Mellitus }\end{array}$ & $\begin{array}{l}\text { Knowledge } \\
\text { Management }\end{array}$ \\
\hline 8. & Mobigame & $\begin{array}{l}\text { To implement } \\
\text { evidence-based sports } \\
\text { scientific knowledge }\end{array}$ & $\begin{array}{l}\text { A mobile system with sensor tracking to verify } \\
\text { the execution } \\
\text { and completion of workouts }\end{array}$ & $\begin{array}{l}\text { Cognitive (Appli- } \\
\text { cation) }\end{array}$ & Cognitive & $\begin{array}{l}\text { Promoting } \mathrm{PA}^{* 1} \text { in } \\
\text { chronic diseases }\end{array}$ & $\begin{array}{l}\text { Patients, } \geq 65 \\
\text { years old/Both }\end{array}$ & Type 2 & $\begin{array}{l}\text { Physical Ac- } \\
\text { tivity }\end{array}$ \\
\hline 9. & $\begin{array}{l}\text { Escape from } \\
\text { DIAB / } \\
\text { Nanoswarm }\end{array}$ & $\begin{array}{l}\text { To Teach about } \\
\text { Nutrition, physical ac- } \\
\text { tivity and energy bal- } \\
\text { ance }\end{array}$ & $\begin{array}{l}\text { Epic games contain nine goal-tasks episodes. } \\
\text { Each episode contains educational mini-games } \\
\text { on PA, nutrition and energy balance with }\end{array}$ & $\begin{array}{l}\text { Cognitive } \\
\text { (Knowledge) }\end{array}$ & $\begin{array}{l}\text { self-Determina- } \\
\text { tion }\end{array}$ & & $\begin{array}{l}\text { Patients, } \\
, 45-70 \text { years } \\
\text { old/ Both }\end{array}$ & Type 2 & $\begin{array}{l}\text { Physical Ac- } \\
\text { tivity }\end{array}$ \\
\hline 10. & $\begin{array}{l}\text { Eindhoven Dia- } \\
\text { betes Education } \\
\text { Simulator (E- } \\
\text { DES) }\end{array}$ & $\begin{array}{l}\text { To generate glucose } \\
\text { and insulin predictions } \\
\text { based food, exercise, } \\
\text { medication and patient } \\
\text { characteristics }\end{array}$ & $\begin{array}{l}\text { Using } 8 \text { concepts, the four concepts are a digi- } \\
\text { tal board game, a quiz platform, a lifestyle sim- } \\
\text { ulator, and a puzzle game. The Diabetes Game } \\
\text { resulted in another digital board game, two } \\
\text { mobile swipe games, and a fairy tale-themed } \\
\text { adventure game }\end{array}$ & $\begin{array}{l}\text { Cognitive } \\
\text { (Knowledge) }\end{array}$ & - & $\begin{array}{l}\text { Effectiveness on } \\
\text { choosing the most } \\
\text { promising concept } \\
\text { from eight different } \\
\text { options. }\end{array}$ & $\begin{array}{l}\text { Children, } 10-12 \\
\text { years old/ Both }\end{array}$ & Type 2 & Nutrition \\
\hline 11. & Mario Brothers & $\begin{array}{l}\text { To promote health-re- } \\
\text { lated behaviors }\end{array}$ & $\begin{array}{l}\text { Open-source } 2 \mathrm{D} \text { mobile game. Three design } \\
\text { strategies, namely Structure, Feedback, and } \\
\text { Challenge Enhancement. The health problems } \\
\text { to be solved by the game player. }\end{array}$ & $\begin{array}{l}\text { Cognitive (Appli- } \\
\text { cation) }\end{array}$ & Cognitive & $\begin{array}{l}\text { Engaging and im- } \\
\text { proving knowledge } \\
\text { of healthy diet and } \\
\text { lifestyle in children. }\end{array}$ & $\begin{array}{l}\text { Patients, } 50-65 \\
\text { years old/ Both }\end{array}$ & Both & $\begin{array}{l}\text { Education Dia- } \\
\text { betic }\end{array}$ \\
\hline 12. & $\begin{array}{l}\text { L'Affaire Bir- } \\
\text { man }\end{array}$ & $\begin{array}{l}\text { To evaluate the effect } \\
\text { of videogame on the } \\
\text { therapeutic knowledge } \\
\text { and behavior of type } 1 \\
\text { diabetes children with }\end{array}$ & $\begin{array}{l}\text { Web-based free videogame based on problem- } \\
\text { solving. Interaction is made by a semi-quanti- } \\
\text { tative glycemic simulator and adapts insulin } \\
\text { dose injection for each meal according to char- } \\
\text { acter's parameters }\end{array}$ & $\begin{array}{l}\text { Cognitive (Evalu- } \\
\text { ation) }\end{array}$ & Situated learning & $\begin{array}{l}\text { Improvement of in- } \\
\text { sulin } \\
\text { and carbohydrate } \\
\text { quantification in } \\
\text { children with type } 1 \\
\text { diabetes }\end{array}$ & $\begin{array}{l}\text { Children, 9-13 } \\
\text { years old/ Both }\end{array}$ & Both & $\begin{array}{l}\text { Education Dia- } \\
\text { betic }\end{array}$ \\
\hline
\end{tabular}




\begin{tabular}{|c|c|c|c|c|c|c|c|c|c|}
\hline Row & Game name & $\mathrm{Aim} / \mathrm{s}$ & Features & $\begin{array}{l}\text { Learning Do- } \\
\text { main(sub domain) }\end{array}$ & Learning Theory & Effectiveness & $\begin{array}{l}\text { Target Audi- } \\
\text { ence/gender }\end{array}$ & $\begin{array}{l}\text { Type of Dia- } \\
\text { betes }\end{array}$ & $\begin{array}{l}\text { Target As- } \\
\text { pects }\end{array}$ \\
\hline 13. & Diab & $\begin{array}{l}\text { To lower the risk of } \\
\text { obesity and type } 2 \text { dia- } \\
\text { betes by changing } \\
\text { children's diet and PA } \\
\text { behaviors }\end{array}$ & $\begin{array}{l}\text { Diab is a G4H inside a three-dimensional set- } \\
\text { ting and has nine episodes. Players guided his } \\
\text { new friends to eat more healthily and to engage } \\
\text { in more physical activity. }\end{array}$ & $\begin{array}{l}\text { Cognitive (Appli- } \\
\text { cation) }\end{array}$ & $\begin{array}{l}\text { Social cognitive, } \\
\text { self-determina- } \\
\text { tion, and persua- } \\
\text { sion }\end{array}$ & $\begin{array}{l}\text { Confirmed the ac- } \\
\text { ceptability and ap- } \\
\quad \text { plicability } \\
\text { of Diab to Hong } \\
\text { Kong Chinese chil- } \\
\text { dren }\end{array}$ & $\begin{array}{l}\text { Patients, } 11-18 \\
\text { years old/ Both }\end{array}$ & Type 1 & $\begin{array}{l}\text { Insulin Ther- } \\
\text { apy }\end{array}$ \\
\hline 14. & $\begin{array}{l}\text { Koodak-e-Ta- } \\
\text { vana }\end{array}$ & $\begin{array}{l}\text { To reduce the behav- } \\
\text { ioral distress due to in- } \\
\text { sulin injection in chil- } \\
\text { dren with type } 1 \text { diabe- } \\
\text { tes }\end{array}$ & $\begin{array}{l}\text { Interactive computer game, with seven parts } \\
\text { including: paired game familiarize with equip- } \\
\text { ment for insulin injection; puzzle game; ques- } \\
\text { tion and answer game; insulin kit game; paint- } \\
\text { ing room; story game; simulated environment } \\
\text { for insulin injection }\end{array}$ & $\begin{array}{l}\text { Cognitive (Appli- } \\
\text { cation) }\end{array}$ & Scaffolding & $\begin{array}{l}\text { Decreasing behav- } \\
\text { ioral distress in- } \\
\text { duced by insulin in- } \\
\text { jection in type } 1 \text { dia- } \\
\text { betic child. }\end{array}$ & $\begin{array}{l}\text { Students, } \\
\text { 9-12 years old / } \\
\text { Both }\end{array}$ & Type 2 & $\begin{array}{l}\text { Nutrition and } \\
\text { Physical Ac- } \\
\text { tivity }\end{array}$ \\
\hline 15. & Inso Online & $\begin{array}{l}\text { compared effective- } \\
\text { ness of InsuOnline, as } \\
\text { to a traditional educa- } \\
\text { tional activity }\end{array}$ & $\begin{array}{l}\text { a Blender 3D app, with simple commands, us- } \\
\text { ing Unity, and visual elements }\end{array}$ & $\begin{array}{l}\text { Cognitive (Appli- } \\
\text { cation) }\end{array}$ & $\begin{array}{l}\text { Problem-based } \\
\text { learning }\end{array}$ & $\begin{array}{l}\text { InsuOnline is as ef- } \\
\text { fective as a tradi- } \\
\text { tional educational } \\
\text { activity on insulin } \\
\text { therapy }\end{array}$ & $\begin{array}{l}\text { Patients, 3-12 } \\
\text { year/ Both }\end{array}$ & Type 1 & $\begin{array}{l}\text { Insulin Injec- } \\
\text { tion }\end{array}$ \\
\hline 16. & $\begin{array}{l}\text { Nintendo Wii } \\
\text { Fit Plus }\end{array}$ & $\begin{array}{l}\text { To determine oxygen } \\
\text { uptake during Wii Fit } \\
\text { Plus use relative to } \\
\text { vO2peak in elderly } \\
\text { type } 2 \text { diabetic patients }\end{array}$ & $\begin{array}{l}\text { Nintendo exergame, with Combination of } \\
\text { physical activity and video games }\end{array}$ & $\begin{array}{l}\text { Cognitive (Evalu- } \\
\text { ation) }\end{array}$ & Not Mentioned & $\begin{array}{l}\text { Improving cardi- } \\
\text { orespiratory fitness } \\
\text { and glucose metabo- } \\
\text { lism. }\end{array}$ & $\begin{array}{l}\text { Undergraduate } \\
\text { medical stu- } \\
\text { dents and Inter- } \\
\text { nal Medicine } \\
\text { residents/ Both }\end{array}$ & $\begin{array}{l}\text { Diabetes } \\
\text { Mellitus }\end{array}$ & $\begin{array}{l}\text { Insulin Ther- } \\
\text { apy }\end{array}$ \\
\hline 17. & Inso Online & $\begin{array}{l}\text { To assess usability and } \\
\text { playability of Insu- } \\
\text { OnLine }\end{array}$ & $\begin{array}{l}\text { A Blender 3D app, with simple commands, us- } \\
\text { ing Unity, and visual elements suite }\end{array}$ & $\begin{array}{l}\text { Cognitive (Appli- } \\
\text { cation) }\end{array}$ & $\begin{array}{l}\text { Problem-Based } \\
\text { Learning }\end{array}$ & $\begin{array}{l}\text { was rated by users } \\
\text { as easy to play, fun, } \\
\text { and useful }\end{array}$ & $\begin{array}{l}\text { Patients, } 45 \text { to } \\
70 \text { years old/ } \\
\text { Both }\end{array}$ & type 2 & $\begin{array}{l}\text { Physical Ac- } \\
\text { tivity }\end{array}$ \\
\hline 18. & $\begin{array}{l}\text { Koodak-e-Ta- } \\
\text { vana }\end{array}$ & $\begin{array}{l}\text { To Aim to teach chil- } \\
\text { dren how to inject in- } \\
\text { sulin }\end{array}$ & $\begin{array}{l}\text { Interactive computer game, has seven parts in- } \\
\text { cluding: } 1 \text {.paired game familiarize with equip- } \\
\text { ment needed for insulin injection; } 2 \text {.puzzle } \\
\text { game; } 3 \text {.question and answer game; } 4 \text {.insulin } \\
\text { kit game; } 5 \text {. painting room; } 6 \text {.story game; } \\
\text { 7.creating a simulated environment for insulin } \\
\text { injection }\end{array}$ & $\begin{array}{l}\text { Cognitive (Appli- } \\
\text { cation) }\end{array}$ & Scaffolding & Not Mentioned & $\begin{array}{l}\text { medical stu- } \\
\text { dents and resi- } \\
\text { dents /Both }\end{array}$ & $\begin{array}{l}\text { Diabetes } \\
\text { Mellitus }\end{array}$ & $\begin{array}{l}\text { Insulin Ther- } \\
\text { apy }\end{array}$ \\
\hline 19. & $\begin{array}{l}\text { Diabetes Visu- } \\
\quad \text { alizer }\end{array}$ & $\begin{array}{l}\text { To provide the user } \\
\text { with skills and } \\
\text { knowledge of how } \\
\text { blood sugars are af- } \\
\text { fected by food, insulin } \\
\text { and activity }\end{array}$ & $\begin{array}{l}\text { Interactive game play, first person visuals and } \\
\text { 3D animated. } \\
\text { The animation allows the viewer to see the } \\
\text { changing status of "blood sugar" over time as } \\
\text { an animated visualization in contrast to the } \\
\text { more static points }\end{array}$ & $\begin{array}{l}\text { Cognitive (Com- } \\
\text { prehension) }\end{array}$ & Not Mentioned & $\begin{array}{l}\text { Effective in engag- } \\
\text { ing participants. }\end{array}$ & $\begin{array}{l}\text { Not Mentioned/ } \\
\text { Not Mrntionrd }\end{array}$ & Type 1 & $\begin{array}{l}\text { Insulin Injec- } \\
\text { tions }\end{array}$ \\
\hline
\end{tabular}

$10 \quad \underline{\mathrm{http}: / / \mathrm{mjiri} . i u m s . a c . i r}$

Med J Islam Repub Iran. 2020 (14 Dec); 34:168. 


\begin{tabular}{|c|c|c|c|c|c|c|c|c|c|}
\hline Row & Game name & $\mathrm{Aim} / \mathrm{s}$ & Features & $\begin{array}{c}\text { Learning Do- } \\
\text { main(subdomain) }\end{array}$ & Learning Theory & Effectiveness & $\begin{array}{l}\text { Target Audi- } \\
\text { ence/gender } \\
\end{array}$ & $\begin{array}{l}\text { Type of Dia- } \\
\text { betes }\end{array}$ & Target Aspects \\
\hline 20. & Wii Fit Plus & $\begin{array}{l}\text { To improve HbAlc as } \\
\text { well as weight, cardi- } \\
\text { ometabolic risk fac- } \\
\text { tors, physical activity } \\
\text { and quality of life in } \\
\text { T2DM patients. }\end{array}$ & $\begin{array}{l}\text { Nintendos exergame and Combination } \\
\text { of physical activity and video games. }\end{array}$ & $\begin{array}{l}\text { Cognitive (Applica- } \\
\text { tion) }\end{array}$ & Not Mentioned & $\begin{array}{l}\text { Improving PA, glucomet- } \\
\text { abolic control and quality } \\
\text { of life in T2DM patients }\end{array}$ & $\begin{array}{l}\text { Not Mentioned/ } \\
\text { Not Mentioned }\end{array}$ & Both & $\begin{array}{l}\text { Self-Manage- } \\
\text { ment }\end{array}$ \\
\hline 21. & Cyber-cycle & $\begin{array}{l}\text { To improve physical } \\
\text { activity }\end{array}$ & $\begin{array}{l}\text { Stationary bike with a video screen that } \\
\text { displays interactive virtual game com- } \\
\text { ponents. }\end{array}$ & $\begin{array}{l}\text { Cognitive } \\
\text { (Knowledge) }\end{array}$ & Cognitive & $\begin{array}{l}\text { Older adults with and } \\
\text { without diabetes were } \\
\text { able to use cyber-cycles } \\
\text { successfully. }\end{array}$ & $\begin{array}{l}\text { Patients, } 50-75 \\
\text { years old /Both }\end{array}$ & Type 2 & $\begin{array}{l}\text { Physical Ac- } \\
\text { tivity }\end{array}$ \\
\hline 22. & $\begin{array}{l}\text { Dance Dance } \\
\text { Revolution }\end{array}$ & $\begin{array}{l}\text { To improve physical } \\
\text { activity }\end{array}$ & $\begin{array}{l}\text { Exer-game with the potential for a } \\
\text { workout progression from basic to ad- } \\
\text { vanced physical } \\
\text { challenges }\end{array}$ & $\begin{array}{l}\text { Cognitive (Applica- } \\
\text { tion) }\end{array}$ & Flow theory & $\begin{array}{l}\text { Effective in meeting vig- } \\
\text { orous PA requirements }\end{array}$ & $\begin{array}{l}\text { Adults, } 60 \text { to } 88 \\
\text { years old / Both }\end{array}$ & $\begin{array}{l}\text { Diabetes } \\
\text { Mellitus }\end{array}$ & $\begin{array}{l}\text { Physical Ac- } \\
\text { tivity }\end{array}$ \\
\hline 23. & SNAP system & $\begin{array}{l}\text { To deliver an enter- } \\
\text { taining gaming experi- } \\
\text { ence with a long-term } \\
\text { solution to physical in- } \\
\text { activity }\end{array}$ & $\begin{array}{l}\text { SNAP system, inspired primarily by the } \\
\text { novelty } \\
\text { introduced by Nintendo Wii and its ina- } \\
\text { bility to } \\
\text { enforce full-body activity }\end{array}$ & $\begin{array}{l}\text { Cognitive (Applica- } \\
\text { tion) }\end{array}$ & Flow & $\begin{array}{l}\text { Providing the added ben- } \\
\text { efit of greater access to } \\
\text { lots of user pose data in- } \\
\text { stead of SNAP system. }\end{array}$ & $\begin{array}{l}\text { Adult, } 18-53 \\
\text { years old/ Both }\end{array}$ & $\begin{array}{l}\text { Not Men- } \\
\text { tioned }\end{array}$ & $\begin{array}{l}\text { Physical Ac- } \\
\text { tivity }\end{array}$ \\
\hline 24. & Balance & $\begin{array}{l}\text { To address the target } \\
\text { group of teenagers and } \\
\text { to integrate the self- } \\
\text { management process } \\
\text { with its challenges and } \\
\text { dangers in the overall } \\
\text { gameplay }\end{array}$ & $\begin{array}{l}\text { Jump'n'Run game. The goal is to free } \\
\text { sb who were captured by strangers. } \\
\text { Should control blood sugar level by eat- } \\
\text { ing food and taking insulin. }\end{array}$ & $\begin{array}{l}\text { Cognitive (Applica- } \\
\text { tion) }\end{array}$ & Social learning & $\begin{array}{l}\text { Yielding higher game en- } \\
\text { joyment than the implicit } \\
\text { version. }\end{array}$ & $\begin{array}{l}\text { Adult, } 18-27 \\
\text { and } 49-73 \text { years } \\
\text { old /Both }\end{array}$ & $\begin{array}{l}\text { Not Men- } \\
\text { tioned }\end{array}$ & $\begin{array}{l}\text { Physical Ac- } \\
\text { tivity }\end{array}$ \\
\hline 25. & Didget & $\begin{array}{l}\text { To assess the perfor- } \\
\text { mance and acceptabil- } \\
\text { ity of a blood glucose } \\
\text { meter in type } 1 \text { diabe- } \\
\text { tes }\end{array}$ & $\begin{array}{l}\text { based on the CONTOUR } ® \text { blood glu- } \\
\text { cose meter that connects to Nintendo } \\
\text { game systems, including Nintendo DS } \\
\text { and Nintendo DS Lite }\end{array}$ & $\begin{array}{l}\text { Cognitive (Applica- } \\
\text { tion) }\end{array}$ & Not Mentioned & $\begin{array}{l}\text { The Didget system was } \\
\text { precise and clinically ac- } \\
\text { curate in the hands of pe- } \\
\text { diatric subjects. }\end{array}$ & $\begin{array}{l}\text { Patients, } 11-16 \\
\text { years old /Both }\end{array}$ & Type 1 & $\begin{array}{l}\text { Self-Manage- } \\
\text { ment }\end{array}$ \\
\hline 26. & $\begin{array}{l}\text { Escape From } \\
\text { Diab }\end{array}$ & $\begin{array}{l}\text { To promote and man- } \\
\text { age energy }\end{array}$ & $\begin{array}{l}\text { Nine-level action-adventure video game } \\
\text { and third-person perspective. }\end{array}$ & $\begin{array}{l}\text { Cognitive (Applica- } \\
\text { tion) }\end{array}$ & $\begin{array}{l}\text { Social-cognitive, } \\
\text { Self-Determina- } \\
\text { tion }\end{array}$ & $\begin{array}{l}\text { Effective at achieving } \\
\text { change in both diet and } \\
\text { PA. }\end{array}$ & $\begin{array}{l}\text { Participants, } 5- \\
24 \text { years old } \\
\text { /Both }\end{array}$ & Type 1 & Treatment \\
\hline
\end{tabular}




\begin{tabular}{|c|c|c|c|c|c|c|c|c|c|}
\hline Row & Game name & Aim/s & Features & $\begin{array}{c}\text { Learning Do- } \\
\text { main(subdomain) }\end{array}$ & Learning Theory & Effectiveness & $\begin{array}{l}\text { Target Audience/ } \\
\text { gender }\end{array}$ & $\begin{array}{l}\text { Type of Di- } \\
\text { abetes }\end{array}$ & Target Aspects \\
\hline 27. & Hangman & $\begin{array}{l}\text { To improve nutritional } \\
\text { goals embedded within } \\
\text { the game }\end{array}$ & $\begin{array}{l}\text { Classic guessing game. having six guesses to } \\
\text { estimate the calories or carbohydrates in a } \\
\text { given food }\end{array}$ & $\begin{array}{c}\text { Cognitive } \\
\text { (Knowledge) }\end{array}$ & $\begin{array}{l}\text { Tailoring, Scaf- } \\
\text { folding }\end{array}$ & Not Mentioned & $\begin{array}{l}\text { middle school } \\
\text { youth /Both }\end{array}$ & Type 2 & $\begin{array}{l}\text { Nutrition and } \\
\text { Physical Activ- } \\
\text { ity }\end{array}$ \\
\hline 28. & QuizShow & $\begin{array}{l}\text { To improve nutritional } \\
\text { goals embedded within } \\
\text { the game }\end{array}$ & $\begin{array}{l}\text { Answering nutrition questions. The gameplay } \\
\text { models in Hangman and QuizShow both rein- } \\
\text { force nutritional estimation skills while playing } \\
\text { a familiar game }\end{array}$ & $\begin{array}{l}\text { Cognitive } \\
\text { (Application) }\end{array}$ & $\begin{array}{l}\text { Tailoring, Scaf- } \\
\text { folding }\end{array}$ & Not Mentioned & Not Mentioned & Both & Nutrition \\
\hline 29. & Countdown & $\begin{array}{l}\text { To improve nutritional } \\
\text { goals embedded within } \\
\text { the game }\end{array}$ & $\begin{array}{l}\text { Focuses on food comparison skills and re- } \\
\text { ceives more points for faster correct responses }\end{array}$ & $\begin{array}{l}\text { Cognitive } \\
\text { (Application) }\end{array}$ & $\begin{array}{l}\text { Tailoring, Scaf- } \\
\text { folding }\end{array}$ & Not Mentioned & Not Mentioned & Both & Nutrition \\
\hline 30. & Nanoswarm & $\begin{array}{l}\text { To educate about en- } \\
\text { ergy balance }\end{array}$ & $\begin{array}{l}\text { First-person perspective uses live actors and } \\
\text { blue screen technology. The player participates } \\
\text { in behavior change components embedded in } \\
\text { gameplay }\end{array}$ & $\begin{array}{l}\text { Cognitive } \\
\text { (Knowledge) }\end{array}$ & $\begin{array}{l}\text { Social Cognitive, } \\
\text { Self -Determina- } \\
\text { tion }\end{array}$ & $\begin{array}{l}\text { effective medium } \\
\text { for promoting youth } \\
\text { diabetes and obesity } \\
\text { prevention }\end{array}$ & Not Mentioned & Both & Nutrition \\
\hline 31. & INSULOT & $\begin{array}{l}\text { To encourage, moti- } \\
\text { vate, and boost the } \\
\text { confidence of type } 1 \\
\text { diabetic patient and to } \\
\text { teach the relationships } \\
\text { among plasma glucose } \\
\text { level, food and insulin } \\
\text { dosage }\end{array}$ & $\begin{array}{l}\text { Three-window slot machine and uses algo- } \\
\text { rithms to simulate postprandial glucose levels. } \\
\text { It is a Java } 2 \text { Micro Edition application. The } \\
\text { application can run as a stand-alone and also } \\
\text { be integrated into a World Wide Web environ- } \\
\text { ment. }\end{array}$ & $\begin{array}{l}\text { Cognitive } \\
\text { (Knowledge) }\end{array}$ & Cognitive & $\begin{array}{l}\text { Patients thought that } \\
\text { game recommended } \\
\text { to other type } 1 \text { dia- } \\
\text { betic patients. } \\
\text { its usability was } \\
\text { highly scored }\end{array}$ & $\begin{array}{l}\text { Youth from mul- } \\
\text { tiple ethnic } \\
\text { groups, 9-11year- } \\
\text { old /Both }\end{array}$ & Type 2 & $\begin{array}{l}\text { Energy Bal- } \\
\text { ance }\end{array}$ \\
\hline 32. & Tamagoya & $\begin{array}{l}\text { To understand general } \\
\text { idea regarding rela- } \\
\text { tionships among } \\
\text { plasma glucose, insu- } \\
\text { lin prescription, food } \\
\text { taking and exercise. }\end{array}$ & $\begin{array}{l}\text { PC game, should choose one of the following } \\
\text { actions: providing food, insulin and exercise }\end{array}$ & $\begin{array}{l}\text { Cognitive } \\
\text { (Application) }\end{array}$ & Not Mentioned & $\begin{array}{l}\text { Balance between en- } \\
\text { tertainment and } \\
\text { learning is a critical } \\
\text { factor in developing } \\
\text { attractive and effec- } \\
\text { tive learning tools. }\end{array}$ & $\begin{array}{l}\text { Patients, } 12-24 \\
\text { years of age } \\
\text { /Both }\end{array}$ & Type 1 & Nutrition \\
\hline
\end{tabular}

12 http://mjiri.iums.ac.ir

Med J Islam Repub Iran. 2020 (14 Dec); 34:168. 


\begin{tabular}{|c|c|c|c|c|c|c|c|c|c|}
\hline Row & Game name & $\mathrm{Aim} / \mathrm{s}$ & Features & $\begin{array}{c}\text { Learning Do- } \\
\text { main(subdomain) }\end{array}$ & Learning Theory & effectiveness & $\begin{array}{l}\text { Target Audi- } \\
\text { ence/gender }\end{array}$ & $\begin{array}{c}\text { Type of } \\
\text { Diabetes }\end{array}$ & Target Aspects \\
\hline 33. & Tantei & $\begin{array}{l}\text { To understand general } \\
\text { idea regarding rela- } \\
\text { tionships among } \\
\text { plasma glucose, insu- } \\
\text { lin prescription, food } \\
\text { taking and exercise. }\end{array}$ & $\begin{array}{l}\text { Type } 1 \text { diabetes player is detective who chases } \\
\text { a criminal in game. The right food and insulin } \\
\text { based on plasma glucose should be finding on } \\
\text { the way to chase criminal. }\end{array}$ & $\begin{array}{l}\text { Cognitive (Appli- } \\
\text { cation) }\end{array}$ & Not Mentioned & $\begin{array}{l}\text { Balance between enter- } \\
\text { tainment and learning is a } \\
\text { critical factor in develop- } \\
\text { ing attractive and effec- } \\
\text { tive learning tools. }\end{array}$ & Patients /Both & Type 1 & $\begin{array}{c}\text { Nutrition, Physi- } \\
\text { cal Activity and } \\
\text { plasma glucose } \\
\text { level }\end{array}$ \\
\hline 34. & Magic Toom & $\begin{array}{l}\text { To understand general } \\
\text { idea regarding rela- } \\
\text { tionships among } \\
\text { plasma glucose, insu- } \\
\text { lin prescription, food } \\
\text { taking and exercise. }\end{array}$ & $\begin{array}{l}\text { Type } 1 \text { diabetes player is detective who chases } \\
\text { a criminal in game. The right food and insulin } \\
\text { based on plasma glucose should be finding on } \\
\text { the way to chase criminal. }\end{array}$ & $\begin{array}{l}\text { Cognitive (Appli- } \\
\text { cation) }\end{array}$ & Not Mentioned & $\begin{array}{l}\text { Balance between enter- } \\
\text { tainment and learning is a } \\
\text { critical factor in develop- } \\
\text { ing attractive and effec- } \\
\text { tive learning tools. }\end{array}$ & Patients /Both & Type 1 & $\begin{array}{c}\text { Nutrition, Physi- } \\
\text { cal Activity and } \\
\text { plasma glucose } \\
\text { level }\end{array}$ \\
\hline 35. & Not mentioned & $\begin{array}{l}\text { To focus on food pref- } \\
\text { erences on activity } \\
\text { preferences and pat- } \\
\text { terns }\end{array}$ & $\begin{array}{l}\text { The } 41 / 451 / 2 \text {-inch cards were developed and } \\
\text { included a range of foods and activities that } \\
\text { were consumed and engaged. } \\
\text { Attempts were made to match the various pic- } \\
\text { tures of foods with regard to attractiveness }\end{array}$ & $\begin{array}{l}\text { Cognitive (Appli- } \\
\text { cation) }\end{array}$ & Not Mentioned & $\begin{array}{l}\text { The card-sorting tasks are } \\
\text { useful tools for assessing } \\
\text { food and activity prefer- } \\
\text { ences and patterns in } \\
\text { girls. }\end{array}$ & Patients /Both & Type 1 & $\begin{array}{l}\text { Nutrition, Physi- } \\
\text { cal Activity and } \\
\text { plasma glucose } \\
\text { level }\end{array}$ \\
\hline 36. & $\begin{array}{l}\text { Packy \& Mar- } \\
\text { lon }\end{array}$ & $\begin{array}{l}\text { To improve a young } \\
\text { person's self-confi- } \\
\text { dence, ability, and mo- } \\
\text { tivation to undertake } \\
\text { the rigorous self-care } \\
\text { necessary to control } \\
\text { insulin-dependent dia- } \\
\text { betes. }\end{array}$ & $\begin{array}{l}\text { a video game with } 24 \text { levels of play take place } \\
\text { in different place and each level becomes in- } \\
\text { creasingly more difficult to complete. } \\
\text { The characters must save their camp from rats } \\
\text { and mice that have scattered the camp's food } \\
\text { and diabetes supplies. Players must also help } \\
\text { their character monitor blood glucose, take ap- } \\
\text { propriate amounts of insulin, review a diabetes } \\
\text { logbook, and find foods containing the right } \\
\text { number of food exchanges according to the } \\
\text { meal plan. }\end{array}$ & $\begin{array}{l}\text { Cognitive (Appli- } \\
\text { cation) }\end{array}$ & Cognitive & $\begin{array}{l}\text { Improving communica- } \\
\text { tion between parents and } \\
\text { children about diabetes. } \\
\text { Positive health-related be- } \\
\text { havior change, compared } \\
\text { to the control group. } \\
\text { Their self-efficacy for di- } \\
\text { abetes self-care improved. }\end{array}$ & $\begin{array}{l}\text { African } \\
\text { American } \\
\text { School girl, } \\
\text { 8- } 10 \text { years } \\
\text { old / Girl }\end{array}$ & $\begin{array}{l}\text { Not Men- } \\
\text { tioned }\end{array}$ & $\begin{array}{l}\text { Nutrition and } \\
\text { Physical Activity }\end{array}$ \\
\hline 37. & $\begin{array}{l}\text { Activity Activ- } \\
\text { ity }\end{array}$ & $\begin{array}{l}\text { To Teach adolescents } \\
\text { strategies for recogniz- } \\
\text { ing and balancing vari- } \\
\text { ations in Physical ac- } \\
\text { tivity with food or in- } \\
\text { sulin }\end{array}$ & $\begin{array}{l}4 \times 6 \text { index cards. Each index card depicts phys- } \\
\text { ical activity and duration, an insulin adjustment } \\
\text { and an amount of a particular food with the ex- } \\
\text { change and carbohydrate equivalents. The } \\
\text { game was played in small groups of } 3 \text { to } 4 \\
\text { teams of campers during one of their four regu- } \\
\text { larly scheduled, } 45 \text {-minute education sessions. }\end{array}$ & $\begin{array}{c}\text { Cognitive } \\
\text { (Knowledge) }\end{array}$ & Not Mentioned & $\begin{array}{l}\text { Enthusiasm and participa- } \\
\text { tion rates were impres- } \\
\text { sively high. } \\
\text { Learning appeared to take } \\
\text { place because the pace } \\
\text { and sophistication of the } \\
\text { game increased substan- } \\
\text { tially with each succeed- } \\
\text { ing round of play. }\end{array}$ & $\begin{array}{l}\text { Patients, } 8 \text { - } \\
16 \text { years old } \\
\text { /Both }\end{array}$ & Type 1 & Self-Care \\
\hline
\end{tabular}




\begin{tabular}{|c|c|c|c|c|c|c|c|c|c|}
\hline Row & Game name & Aim/s & Features & $\begin{array}{c}\text { Learning Do- } \\
\text { main(subdomain) }\end{array}$ & Learning Theory & effectiveness & $\begin{array}{l}\text { Target Audi- } \\
\text { ence/gender }\end{array}$ & $\begin{array}{c}\text { Type of Dia- } \\
\text { betes }\end{array}$ & Target Aspects \\
\hline 38. & $\begin{array}{l}\text { Tic-Tac-Diabe- } \\
\text { tes }\end{array}$ & $\begin{array}{l}\text { To stimulate participa- } \\
\text { tion in the learning } \\
\text { process. }\end{array}$ & $\begin{array}{l}4 \times 4 \text {-foot game board and wooden X's and } \\
\text { O's that could be hung on hooks in each square } \\
\text { were constructed. Nine categories of questions } \\
\text { were created for each of the tic-tac-toe squares. }\end{array}$ & $\begin{array}{c}\text { Cognitive } \\
\text { (Knowledge) }\end{array}$ & Not Mentioned & Not Mentioned & $\begin{array}{c}\text { Youth, } 9-15 \\
\text { years old /Both }\end{array}$ & $\begin{array}{l}\text { Not Men- } \\
\text { tioned }\end{array}$ & Physical Activity \\
\hline 39. & $\begin{array}{l}\text { What's wrong } \\
\text { with This Pic- } \\
\text { ture? }\end{array}$ & $\begin{array}{l}\text { To teach and heighten } \\
\text { participants' aware- } \\
\text { ness of their own mis- } \\
\text { conceptions diabetic } \\
\text { diet }\end{array}$ & $\begin{array}{l}\text { Pictures of each of the different foods from } \\
\text { each exchange list were arranged on cards, } \\
\text { with one of the foods being inappropriately } \\
\text { Placed within the food group. The participants } \\
\text { were given answer sheets to record their indi- } \\
\text { vidual responses. }\end{array}$ & $\begin{array}{c}\text { Cognitive } \\
\text { (Knowledge) }\end{array}$ & Not Mentioned & Not Mentioned & Not Mentioned & $\begin{array}{l}\text { Not Men- } \\
\text { tioned }\end{array}$ & $\begin{array}{l}\text { Hyperglycemia- } \\
\text { Medications Hy- } \\
\text { giene and Foot } \\
\text { Care-Blood Glu- } \\
\text { cose Monitoring }\end{array}$ \\
\hline 40. & $\begin{array}{l}\text { Can You Guess } \\
\text { Your Blood } \\
\text { Sugar'? }\end{array}$ & $\begin{array}{l}\text { To assist staff in be- } \\
\text { coming familiar with } \\
\text { the different types of } \\
\text { home blood glucose } \\
\text { monitors } \\
\text { To Know the difficul- } \\
\text { ties some individuals } \\
\text { with diabetes encoun- } \\
\text { ter when learning to } \\
\text { perform self-testing }\end{array}$ & $\begin{array}{l}\text { The game begins with an explanation and } \\
\text { demonstration of blood glucose monitoring } \\
\text { equipment. During the demonstration, each } \\
\text { participant's blood glucose level was moni- } \\
\text { tored. participants were asked to guess their } \\
\text { blood glucose levels and to determine the accu- } \\
\text { racy of their guess }\end{array}$ & $\begin{array}{l}\text { Cognitive (Appli- } \\
\text { cation) }\end{array}$ & Not Mentioned & Not Mentioned & Not Mentioned & $\begin{array}{l}\text { Not Men- } \\
\text { tioned }\end{array}$ & Nutrition \\
\hline 41. & Betakid & $\begin{array}{l}\text { To provide an oppor- } \\
\text { tunity for diabetic chil- } \\
\text { dren to practice and } \\
\text { evaluate skills in food } \\
\text { and insulin dose selec- } \\
\text { tion }\end{array}$ & $\begin{array}{l}\text { the simulation begins with a graphic of Betakid } \\
\text { awakened by his alarm clock Additional events } \\
\text { in Betakid's day follow a typical adolescent's } \\
\text { Activities: meals, classes at school, exercise, } \\
\text { and after-school activities. A multiple-choice } \\
\text { format for food, insulin, and exercise decisions } \\
\text { was used. The current blood glucose level is a } \\
\text { factor in determining if a decision is correct. }\end{array}$ & $\begin{array}{c}\text { Cognitive } \\
\text { (Knowledge) }\end{array}$ & Not Mentioned & Not Mentioned & Not Mentioned & $\begin{array}{l}\text { Diabetes } \\
\text { Mellitus }\end{array}$ & $\begin{array}{l}\text { Nutrition and In- } \\
\text { sulin Dose }\end{array}$ \\
\hline
\end{tabular}

14 http://mjiri.iums.ac.ir 


\section{Acknowledgment}

This document represents the findings of a Ph.D. project at Iran University of Medical Sciences. The secured reference number of the code of ethics to conduct the project is IR.IUMS.FMD.REC 1396.9421623001 and the project is funded by Iran University of Medical Sciences.

\section{Conflict of Interests}

The authors declare that they have no competing interests.

\section{References}

1. Chan M. Global Report on Diabetes World Health Organization: World Health Organization; 2017 [cited 2019 Feb 16]. Available from: https://apps.who.int/iris/bitstream/handle/10665/204871/97892 41565257_eng.pdf;jsessionid=DA58C69B1AB84B566D73745FB86 E8430?sequence $=1$.

2. Centers for Disease Control and Prevention, National Diabetes Statistics Report, 2017: Centers for Disease Control and Prevention (CDC)2017 [cited 2018 May, 1]. Available from: https://www.cdc.gov/diabetes/pdfs/data/statistics/ national-diabetesstatistics-report.pdf.

3. Vares Z, Zandi M, Baghaei P, Alavi N, Ajorpaz N. Quality of life and related factors in diabetic patients attending a diabetes center in Kashan. Nurs Res. 2010;5(17):14-22.

4. Praet SF, Van Loon LJ. Optimizing the therapeutic benefits of exercise in type 2 diabetes. JAPPL. 2007;103(4):1113-20.

5. Bajpeyi S, Tanner CJ, Slentz CA, Duscha BD, McCartney JS, Hickner $\mathrm{RC}$, et al. Effect of exercise intensity and volume on persistence of insulin sensitivity during training cessation. JAPPL. 2009;106(4):107985.

6 Smeltzer B. Text Book of Medical-Surgical Nursing. 6th ed ed. Philadelphia: J. B. Lipincott; 2002.

7. White P, Smith SM, Hevey D, O'dowd T. Understanding Type 2 Diabetes. TDE. 2009;35(5):810-7.

8. Chlebowy DO, Hood S, LaJoie AS. Facilitators and barriers to selfmanagement of type 2 diabetes among urban African American adults. TDE. 2010;36(6):897-905.

9. Emami Moghaddam Z, Hasanzadeh F, Namavar M, Khorsand M, Khazaei G, Esmaeili H. The effect of home visit on the manner of self care in leprotic patients. JMRH. 2009;9(2):101-106. (Persian).

10. Miri F, Khodaveisi M, Karami M, Mohammadi N. The Effect of training home care to type-2 diabetic patients on controlling blood glucose levels in patients admitted to the diabetes research center of Hamadan. SJHNMF. 2014;22(3):24-32.

11. Ghorbani A, Arjini Z, Teymori R. Comparison the effects of electronic education with the printed material on knowledge of diabetic self-care patients. J Qazvin Univ Med Sci. 2015;18(6):63-6.

12. Groh F. Gamification: State of the art definition and utilization. UULM. 2012;39:31.

13. Bigdeli S, Kaufman D. Digital games in medical education: Key terms, concepts, and definitions. MJIRI. 2017;31:52.

14. Barab S, Dede C. Games and immersive participatory simulations for science education: an emerging type of curricula. JSET. 2007;16(1):13.

15. Alvarez J, Djaouti D. An introduction to Serious game Definitions and concepts. SGSRM. 2011;11:11-5.

16. Al-Azawi R, Al-Faliti F, Al-Blushi M. Educational gamification vs. game based learning: Comparative study. IJIMT. 2016;7(4):132-6.

17. Lin WC, Ho JY, Lai CH, Jong BS, editors. Mobile game-based learning to inspire students learning motivation. Information Science, Electronics and Electrical Engineering (ISEEE), 2014 International Conference on; 2014: IEEE.

18. Giannakos MN. Enjoy and learn with educational games: Examining factors affecting learning performance. Computers \& Education. 2013;68:429-39.

19. Tobias S, Fletcher J, Dai DY, Wind AP. Review of research on computer games. CGIJ. 2011;127:222.

20. Gee JP. Deep learning properties of good digital games: how far can they go? Serious Games: Routledge; 2009. p. 89-104.

21. Landers RN, Bauer KN, Callan RC. Gamification of task performance with leaderboards: A goal setting experiment. CHBJ. 2017;71:508-15.

22. Tondello G, Premsukh H, Nacke L. A Theory of Gamification Principles Through Goal-Setting Theory. Proceedings of the 51st Hawaii International Conference on System Sciences (HICSS); Hawaii: HICSS; 2018.

23. Cheong C, Cheong F, Filippou J, editors. Quick Quiz: A Gamified Approach for Enhancing Learning. PACIS; 2013.

24. Bicen H, Kocakoyun S. Perceptions of Students for Gamification Approach: Kahoot as a Case Study. IJET. 2018;13(02):72-93.

25. Song D, Shi D, Wang R, Xu H. Splitting and Combining as a Gamification Method in Engaging Structured Knowledge Learning. Sustainability. 2018;10(3):800.

26. Landers RN. Developing a theory of gamified learning: Linking serious games and gamification of learning. Simulation \& Gaming. 2014;45(6):752-68.

27. Miller AS, Cafazzo JA, Seto E. A game plan: gamification design principles in mHealth applications for chronic disease management. HIJ. 2016;22(2):184-93.

28. Schoech D, Boyas JF, Black BM, Elias-Lambert N. Gamification for behavior change: Lessons from developing a social, multiuser, webtablet based prevention game for youths. JTHS. 2013;31(3):197-217.

29. Lewis ZH, Swartz MC EL. What's the point?: A review of reward systems implemented in gamification interventions. Games for health journal. 2016 5(2):93-9.

30. Papp TA, Theresa A. Gamification Effects on Motivation and Learning: Application to Primary and College Students. IJCDSE. 2017;8(3).

31. Bigdeli S, Kaufman D. Digital games in health professions education: Advantages, disadvantages, and game engagement factors. MJIRI. 2017;31(1):780-5.

32. Matallaoui A, Koivisto J, Hamari J. How effective is "exergamification"? A systematic review on the effectiveness of gamification features in exergames. In: $\mathrm{R} Z$, editor. Proceedings of the 50th Hawaii International Conference on System Sciences 2017; University of Hawai'i at Manoa: University of Hawai'i at Manoa 2017.

33. KA M. Literature review: Effectiveness of gaming in the classroom. Michigan State University: Michigan State University; 2006.

34. Plessis I. The Effectiveness Of Gamification As An E-Learning Strategy. IJMAS. 2017;3(7):24-6.

35. Gough,C Value of the gamification market worldwide in 2016 and 2021 (in billion U.S. dollars): Statista; 2018. Available from: https://www.statista.com/statistics/608824/ gamification-marketvalue-worldwide/.

36. Morschheuser B, Hamari J, Werder K, Abe J, editors. How to gamify? A method for designing gamification. Hawaii International Conference on System Sciences 50th Anniversary; 2017: Hawaii HICSS.Morschheuser, Benedikt.

37. Steffens F, Marczak S, Treude C, Singer L, editors. Using gamification as a collaboration motivator for software development teams: A preliminary framework. SBSC'15: Brazilian Symp in Collaborative Systems; 2015 